\title{
Inheritance of leaf resistance to Septoria nodorum Berk. in two crosses of spring wheat
}

\author{
REIJO KARJALAINEN
}

Departments of Plant Pathology and Plant Breeding, University of Helsinki, 00710 Helsinki 71 , Finland

\begin{abstract}
The $\mathrm{F}_{2}$ progeny of two spring wheat crosses involving susceptible and moderately resistant parent cultivars were tested in the field for their reaction to infection by Septoria nodorum Berk. The variation in symptom expression was continuous, providing no support for the existence of individually acting major genes. The broad sense heritability values for the crosses were moderate at 0.47 and 0.34 with over half of the variation being of environmental origin. The results are discussed in relation to developing a resistance breeding strategy for wheat to $S$. nodorum.
\end{abstract}

\section{Introduction}

Septoria nodorum Berk., the cause of the glume blotch disease of wheat, has become a major wheat pathogen in Europe, in several parts of Asia, and in South and North America (SAARI and WILCOXSON 1974).

Resistance is the most feasible method for the control of the diseases in the Septoria complex in terms of economic advantage and long term protection (DOODSON 1981). Genetic progress in breeding for disease resistance depends on several factors, such as the availability of resistant germplasm, appropriate screening techniques, and the nature of the host resistance. Available experimental analyses indicate that the resistance of wheat to $S$. nodorum is under polygenic control and involves several genes (LAUBSCHER et al. 1966, NELSON 1980, MULLANEY et al. 1982, SCOTT et al. 1982). However, there is some evidence that resistance at the seedling stage is conferred by dominant gene(s). KLEIJER et al. (1977) have shown that the cultivar Atlas 66 carries a single dominant gene located on the wheat chromosome $1 \mathrm{~B}$ and this gene is responsible for resistance to $\mathrm{S}$. nodorum at the seedling stage. Recently, SCHAREN and EYAL (1983) have provided further evidence for this phenomenon as they have found that the resistance in highly resistant cultivars may be governed by major R-genes. Hitherto there is no evidence for the existence of single genes which alone could give 
an easily detectable level of resistance at the mature plant stage (SCHAREN and EYAL 1980).

BRÖNNIMANN (1975) has shown tolerance, measured as the loss in 1000 kernel weight, to be polygenically inherited and controlled by additive gene action. Further, KLEIJER et al. (1980) have demonstrated, using the chromosome substitution lines of Thatcher and Timstein, that the cultivar Thatcher carries 12 chromosomes which influence the control of tolerance, nine having a large effect and three having a minor effect. However, only seven chromosomes of Timstein showed a positive effect, suggesting that the interaction effects between chromosomes are important.

Progress in improving quantitatively inherited traits is dependent on the proportion of variation due to genotype and that due to environment. The present preliminary study describes the results of an evaluation of the heritability of leaf resistance to S. nodorum on two crosses of spring wheat.

\section{Materials and methods}

The data reported in this study are based on the trials carried out at the experimental farm of the University of Helsinki. Two $F_{2}$ populations, derived from the crosses Tähti $\times$ TGS $334 / 74 / 8$ and Tähti $\times$ Maris Butler, were investigated. TGS $334 / 74 / 8$ and Maris Butler (obtained from the Cambridge Plant Breeding Institute) are moderately resistant varieties, while the Finnish cultivar Tähti is a susceptible one. The crosses were made during the winter of 1980 in glasshouses. The $F_{1}$ generation was grown in the glasshouse, and it produced, by self-fertilization, material for the $F_{2}$ populations.

Small plots were space-planted with two replications arranged in a randomized block design. Standard fertilization and herbicide treatments were applied. An artifical inoculation technique was used in which inoculum was applied onto the plants by spraying each plant separately and as evenly as possible during or soon after ear emergence. Inoculum consisted of a mixed aqueous suspension of about $10^{6}$ conidia ml-1 obtained from several isolates of S. nodorum. The preparation of inoculum and the culturing techniques of the fungus have been previously described in detail (KARJALAINEN et al. 1983). After inoculation the plants were kept damp by daily irrigation. The assessments of disease severity were made on the flag leaves by estimating the percentage area covered by S. nodorum lesions. The percent values were transformed using the arc-sin transformation. The assessments were carried out twice, 8-12 days after the first inoculation.

The objective of this study was to estimate the proportion of heritable variation of the total variation of disease severity using two $F_{2}$ progenies. Heritability in the broad sense was estimated from the present data, although it is of limited value in predicting breeding success (CAHANER and HILLEL 1980). However, in this case the broad sense heritability estimates were calculated in order to arrive at an upper limit for the narrow sense heritability, and from this the additive component of the total variation can be 
deduced. Heritability in the broad sense was calculated using the following equation that has been cited by several authors (e.g. GRIFFITHS and LAWES 1978).

$$
\begin{aligned}
& V_{F_{2}}-\frac{V_{P_{1}}+V_{P_{2}}}{2} \\
& \mathrm{H}_{\mathrm{bs}}^{2}=\frac{}{\mathrm{V}_{\mathrm{F}_{2}}} \\
& \text { where } \mathrm{H}^{2}{ }_{b s} \quad \text { = heritability in the broad sense } \\
& \mathrm{V}_{\mathrm{F}_{2}} \quad=\text { variance of } \mathrm{F}_{2} \text { generation } \\
& \mathrm{V}_{\mathrm{P}} \quad=\text { variance of parents }
\end{aligned}
$$

In utilizing this variance method the environmental variation was approximated from genetically uniform parent populations. The standard error of the heritability was calculated assuming that the sample variances of the parents and the $F_{2}$ progenies follow the Gamma distribution. Furthermore, the standard error of the heritability was derived assuming that all sample variances are independent.

\section{Results and discussion}

The heritability figures calculated for the $\mathrm{F}_{2}$ crosses of spring wheat are presented in Table 1. The results indicate that in general the $\mathrm{H}^{2}$ values are moderate, and that over half of the variation in the level of disease severity of the $\mathrm{F}_{2}$ generation was of environmental origin. In the present experiment the cross Tähti $\times$ Maris Butler showed a somewhat higher heritability than that of Tähti $\times$ TGS $334 / 74 / 8$, but the standard error of heritability was lower in the first cross. In this experiment the inoculum was applied as evenly as possible to avoid any variation due to the uneven spread of inoculum onto the plants.

From the present experiment it may be concluded that in these particular crosses involving moderately resistant and susceptible parents, the additive genetic variance is rather low and that environmental variation accounts for a major part of the total variation of symptom expression. Hence breeding

Table 1. Means, the standard errors of the means, and the broad sense heritability values and their standard errors calculated for two $\mathrm{F}_{2}$ progenies of spring wheat crosses.

\begin{tabular}{lccc}
\hline \multirow{2}{*}{ Parents and crosses } & \multicolumn{3}{c}{ Mean percent diseased tissue } \\
\cline { 2 - 4 } & $\mathrm{N}$ & $\mathrm{X} \pm \mathrm{SEM}$ & $\mathrm{H}_{\mathrm{bs}}^{2} \pm \mathrm{SE}$ \\
\hline Tähti & 60 & $49.7 \pm 0.22$ & \\
Maris Butler & 70 & $29.9 \pm 0.17$ & \\
TGS 334/74/8 & 70 & $29.3 \pm 0.18$ & \\
Tähti x Maris Butler & 229 & $43.7 \pm 0.07$ & $0.47 \pm 0.05$ \\
Tähti x TGS 334/74/8 & 232 & $37.4 \pm 0.07$ & $0.34 \pm 0.12$ \\
\hline
\end{tabular}


progress depends on the use of efficient screening methods in order to detect the slight differences caused by several minor genes. The variation in disease symptom expression was continuous and there was no evidence of major gene effects.

The evidence obtained from experiments described in the literature have revealed fairly high heritabilities in host resistance to S. nodorum. For example, ROSIELLE and BROWN (1980) indicate heritabilities of $63 \%$ and 52 $\%$ on leaf and ear resistance, respectively. AASTVEIT (1982) has observed heritabilities as high as .89 , but his experiment was carried out using natural infection. BRÖNNIMANN (1975) has analysed heritabilities on the basis of five parent diallel crosses measuring the inheritance of tolerance. The results showed heritabilities of .66 and .65 for the $F_{1}$ and $F_{2}$ generations, respectively. Contrary to these experiments, which have led to high heritability estimates, SCOTT et al. (1982) have provided evidence that in most of their winter wheat crosses the heritabilities were low and the standard errors were high.

The observed diversity in the heritability estimates may be due to several reasons. For example, only a few authors have used the same method of calculating the heritability estimates. Furthermore, standard errors for the obtained $\mathrm{H}^{2}$ estimates have been presented only in some experiments, though in many cases they would provide valuable aid in evaluating the reliability of the results. A great deal of the variation in presented heritabilities may be due to the different procedures and different environmental conditions of the experiments. Inoculation procedures - spraying techniques, spore densities etc. - which affect the reliable ranking of cultivars have also varied amongst studies (SCHAREN and EYAL 1980). Moreover, evidence is now accumulating that this host-pathogen interaction is sensitive to environmental changes. For example, FRIED and BRÖNNIMANN (1982) have observed that environmental conditions after inoculation may mask the genotypic differences between cultivars. The experiment conducted by MULLANEY et al. (1982) substantiate this, since the authors have found that wheat crosses exhibit a strong genotype-environment interaction in relation to disease expression.

It may thus be concluded that it is not possible to make comparisons between different $\mathrm{H}^{2}$ estimates. Each experiment has its own value, applicable only to a specific population and to the specific conditions under which the experiment has been carried out. This is already widely accepted in interpreting the usefulness of heritability values in a general sense (DUDLEY and MOLL 1969).

Recent studies on the genetic control of wheat resistance to S. nodorum throw some light on practical resistance breeding. For example, MULLANEY et al. (1982) have shown that leaf resistance is polygenically determined and can be explained by mainly additive gene effects. A diallel analysis by NELSON (1980) and NELSON and GATES (1982) supports the theory of additive effects in the inheritance of host reaction to S. nodorum. NELSON(1980) also found that general combining ability effects were highly significant, but specific combining ability effects were observed as well, indicating non-additive gene action for some specific crosses. It has been 
recently suggested that cytoplasmic inheritance might be involved in the resistance to S. nodorum(NELSON 1980). However, this assumption remains to be verified.

For the practical resistance breeder it is important that the resistance to $\mathrm{S}$. nodorum is mainly controlled by additively acting genes, as this allows him to accumulate desired genes into populations. Experimental selection trials provide encouraging results, for example, SCHAREN and KRUPINSKY (1978) have obtained positive transgressions in several of their wheat crosses indicating that additively acting minor genes can be accumulated into breeding lines and populations. Thus, since there are good opportunities for developing the selection techniques and the resistance material presently available, it seems that the prospects for breeding S. nodorum resistant wheats are promising. The best evidence for this optimism is the fact that cultivars with a satisfactory degree of resistance have been produced, and the cultivation of these varieties has given good economic return in terms of cost-benefit analysis of crop protection costs (DOODSON 1981).

Acknowledgements. I am grateful to Professor Eeva Tapio for reading the manuscript and Sampo Sirkkomaa for statistical advice. The English text was kindly revised by Ms. Heather MacKenzie and Ms. Sinikka Karjalainen. This work was supported by grants from the August Johannes and Aino Tiuran maatalouden tutkimussäätiö and this support is gratefully acknowledged.

\section{References}

AASTVEIT, K. 1982. Nedarving av resistens mot Septoria nodorum i vårhvete. Nordisk jordbruksforskning 64: 234-239.

BRÖNNIMANN, A. 1975. Beitrag zur Genetik der Toleranz auf Septoria nodorum Berk. bei Weizen (Triticum aestivum). Z. Pflanzenzüchtg. 75: 138-160.

CAHANER, A. HILLEL, J. 1980. Estimating heritability and genetic correlation between traits from generations $\mathrm{F}_{2}$ and $\mathrm{F}_{3}$ of self-fertilizing species: a comparison of three methods. Theor. Appl. Genet. 58: 33-38.

DOODSON; J. K. 1981. The economic contribution of resistant winter wheat varieties J. Natn. Agric. Bot. 15: 413-420.

DUDLEY, J. W. \& MOLL. R. H. 1969. Interpretation and use of estimates of heritability and genetic variances in plant breeding. Crop Science 9: 257-26.

FRIED, P. M. \& BRÖNNIMANN, A. 1982. Septoria nodorum Berk. on wheat: effect of inoculation time and penducle length on yield reduction and disease development. Z. Pflanzenzüchtg. 89:312-328.

GRIFFITHS, D. W. \& LAWES, D. A. 1978. Variation in the crude protein content of field beans (Vicia faba L.) in relation to the possible improvement of the protein content of the crop. Euphytica 27: $487-495$.

KARJALAINEN, R., LAITINEN, A. \& JUUTI, T. 1983. Susceptibility of spring wheat cultivars to Septoria nodorum. J. Scient. Agric. Soc. Finl. 55: 315-332.

KLEIJER, G., BRÖNNIMANN, A. \& FOSSATI, A. 1977. Chromosomal location of a dominant gene for resistance at the seedling stage to Septoria nodorum Berk. in the wheat variety 'Atlas 66'. Z. Pflanzenzüchtg. 78: 170-173.

- , FOSSATI, A. \& PACCAUD, F. X. 1980. Genetic analysis of tolerance to Septoria nodorum Berk. in wheat using chromosome substitution lines. Z. Pflanzenzüchtg. 85: 287-293.

LAUBSCHER, F. X., WECHMAR, B. von \& SCHALKWYK, D. van 1966. Heritable resistance of wheat varieties to glume blotch (Septoria nodorum Berk.). Phytopath. Z. 56: 260-264. 
MULLANEY,E. J., MARTIN, J. M. \& SCHAREN, A. L. 1982. Generation mean analysis to identify and partition the components of genetic resistance to Septoria nodorum in wheat. Euphytica 31: 539-545.

NELSON, L. R. 1980. Inheritance of resistance to Septoria nodorum in wheat. Crop Science 20: 447-449.

- \& GATES, C. T. 1982. Genetics of host plant resistance of wheat to Septoria nodorum. Crop Science 22: 771-773.

ROSIELLE, A. A. \& BROWN, A. G. P. 1980. Selection for resistance to Septoria nodorum in wheat. Euphytica 29: 337-346.

SAARI, E. E. \& WILCOXSON, R. D. 1974. Plant disease situation of high yielding dwarf wheats in Asia and Africa. Ann. Rev. Phytopath. 12: 49-68.

SCHAREN, A. L. \& EYAL, Z. 1980. Measurement of quantitative resistance to Septoria nodorum in wheat. Plant Dis. 65: 492-496.

- \& EYAL, Z. 1983. Analysis of symptoms on spring and winter wheat cultivars inoculated with different isolates of Septoria nodorum Phytopath. 73: 143-147.

- \& KRUPINSKY, J. M. 1978. Detection and manipulation of resistance to Septoria nodorum in wheat. Phytopath. 68: 245-248.

SCOTT, P. R., BENEDIKZ, P. W. \& COX, C. J. 1982. A genetic study of the relationship between height, time of ear emergence and resistance to Septoria nodorum in wheat. Plant Path. 31: 45-60.

Ms received June 6, 1983.

\section{Septoria nodorum Berk. -resistenssin periytymisestä kevätvehnän risteytyksissä}

Reijo Karjalainen

Kasvipatologian ja kasvinjalostustieteen laitos, Helsingin yliopisto, 00710, Helsinki 71

Septoria nodorum -taudin resistenssin periytyvyyttä tutkittiin kahdesta kevätvehnän risteytysjälkeläistöstä, jotka oli saatu risteyttämällä yksi altis ja kaksi kohtalaisen resistenttiä lajiketta. Jälkeläistöjen taudinkestävyys testattiin keinotekoisen saastuntatekniikan avulla Helsingin yliopiston Viikin koetilalla. Tulokset osoittivat, että ympäristövaihtelu selitti yli puolet resistenssin muuntelusta. Periytyvien osien määrät risteytyksissä olivat puolestaan 0,47 ja 0,34 . Tulokset tukevat sitä käsitystä, että resistenssin periytyminen on useiden geenien säätelemää ja ympäristötekijät vaikuttavat voimakkaasti resistenssin ilmenemisasteeseen. Käytännön resistenssijalostuksessa on olennaista, että käytetään mahdollisimman tehokkaita seulontamenetelmiä, joilla voidaan erottaa alttiit ja kestävät yksilöt ja linjat toisistaan. 